\title{
Applications of Fuzz Comprehensive Evaluation in Display and Control System of Armored Vehicle
}

\author{
Nie Jun-feng ${ }^{1, ~ a ~}$, Liu Wei-ping ${ }^{1, b}$, Jin $\mathrm{Yi}^{1, \mathrm{c}}$ and Cao Wei-guo ${ }^{1, \mathrm{c}}$ \\ ${ }^{1}$ Department of Mechanical Engineering Academy \\ of Armored Force Engineering ,Beijing \\ anjf0706@126.com, b18911631756@189.com, ' $13581748524 @ 163 . c o m$
}

Keywords: Armored vehicle; Display and control system; Fuzzy evaluation

\begin{abstract}
In this paper, from the point of view of Man-machine system engineering, the evaluation method of the display and control system is studied based on fuzzy comprehensive evaluation. The determination of the factors system, the weighted value of the factors, the fuzzy evaluation matrixes and the method of overall evaluation is preliminarily expounded. At last, an example is given to show that the proposed method is effective and applicable. It provides a theoretic reference to the integrated display console interface of armored vehicle developing and designing.
\end{abstract}

\section{Introduction}

As the exchange window of information between the crew and armored vehicle, the display and control system is the main channel for access to vehicle information. However, with the information technology widely used in armored vehicles, the display and control interface become increasingly complex. This increases the crew's workload. The lack of an effective system analysis and evaluation during man-machine design process is one of the most important factors [1].

On the basis of comprehensive analysis of the display and control system characteristics, the paper proposes a fuzzy comprehensive evaluation model of the integrated display console interface. The model combines the qualitative and quantitative analysis, compensates the defects of the previous evaluation method. It provides a new approach for the evaluation of complex man-machine system [2].

\section{Evaluation Index System of the Display and Control System}

Display and Control System Structure Model. In order to analyze the basic structure of the display and control system, clear the process of human-machine interaction, understand the human-machine operating characteristics, the paper builds the display and control system structure model.

As the Figure 1 shows, the display and control system is divided into seven subsystems, they are machine perception, machine thinking, actuating mechanism, person perception, manual handing, locomotory and man-machine interface. The subsystems are interrelated and interact on each other. This indicates that, in order to build the index system, not only the hardware and software of the system, but also the crew should be equally important considered. 




Fig. 1 Structure model of display and control system

Evaluation Index System. The synthetic display level and the composite control level do direct impacts on the implementation and completion of the combat missions. Meanwhile, the crew and vehicle interaction ergonomics has a direct reflection of the comfort of the cockpit environment. The level of man-machine cooperation reflects the rationality of the system man-machine function assignment. In the process of completion of the display and control tasks, technological advance is the guarantee. Through the above analysis, the primary factor sets are as follows: synthetic display level, integrated technical level, composite control level, man machine effectiveness level and coordination level. The secondary factor sets determined and so on, as shown in Figure 2.

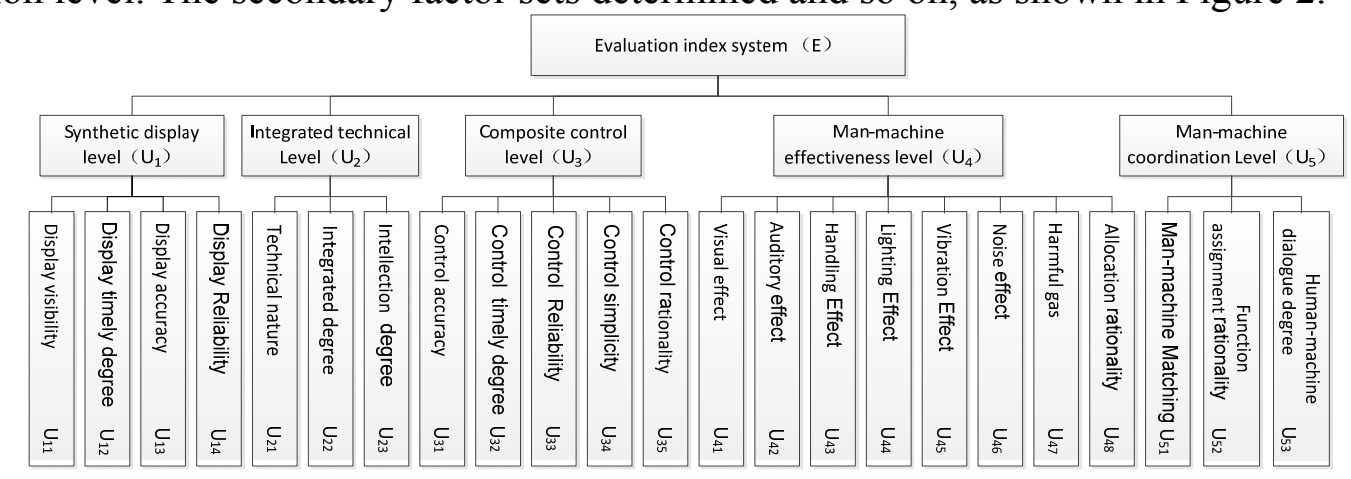

Fig. 2 Evaluation index system

\section{Fuzzy Comprehensive Evaluation Model}

All Levels of Factors Set and Evaluation Set. First, the primary factor sets are created: $\mathrm{U}=\left\{\mathrm{U}_{1}, \mathrm{U}_{2}, \mathrm{U}_{3}, \mathrm{U}_{4}, \mathrm{U}_{5}\right\}$. The secondary factor sets are as follows: $\mathrm{U}_{1}=\left\{\mathrm{U}_{11}, \mathrm{U}_{12}\right.$, $\left.\mathrm{U}_{13}, \mathrm{U}_{14}\right\}, \mathrm{U}_{2}=\left\{\mathrm{U}_{21}, \mathrm{U}_{22}, \mathrm{U}_{23}\right\}, \mathrm{U}_{3}=\left\{\mathrm{U}_{31}, \mathrm{U}_{32}, \mathrm{U}_{33}, \mathrm{U}_{34}, \mathrm{U}_{35}\right\}, \mathrm{U}_{4}=\left\{\mathrm{U}_{41}, \mathrm{U}_{42}, \mathrm{U}_{43}, \mathrm{U}_{44}, \mathrm{U}_{45}, \mathrm{U}_{46}, \mathrm{U}_{47}, \mathrm{U}_{48}\right\}, \mathrm{U}_{5}=\{$ $\left.\mathrm{U}_{51}, \mathrm{U}_{52}, \mathrm{U}_{53}\right\}$.

Then, the evaluation set is divided into five categories: $V=\left\{\mathrm{V}_{1}, \mathrm{~V}_{2}, \mathrm{~V}_{3}, \mathrm{~V}_{4}, \mathrm{~V}_{5}\right\}=\{$ good, better, general, worse, bad\}.Percentage system grading method is used to the evaluation results. The fractional intervals middle value is as the level geometric parameter of the display and control system [3]. And the score interval and the grade parameter are shown in Table 1.

Table 1 Score interval and grade parameter

\begin{tabular}{|c|c|c|c|c|c|}
\hline \multicolumn{7}{|c|}{ Evaluation Set V } \\
\hline Reviews & good & better & general & worse & bad \\
\hline Score interval & {$[90-100]$} & {$[80-90]$} & {$[70-80]$} & {$[60-70]$} & {$[50-60]$} \\
\hline Grade parameter & 95 & 85 & 75 & 65 & 55 \\
\hline
\end{tabular}

Weight Set. As a fuzzy subset, the weight set reflects the degree of importance of the event in the system [4].. In order to give the weighting certain creditability, the weighting coefficients are graded. The weights range[0,1] is divided into five levels, they are $[0,0.2],[0.2,0.4],[0.4,0.6],[0.6,0.8],[0.8,1]$. For each evaluation index, the probability is counted in the weighted interval. And then draw weight vector composed of each evaluation index by 
calculating the expected value. So the weight vector can be determined as: $\omega_{\omega}=\left\{\mathrm{a}_{1}, \mathrm{a}_{2}, \cdots, \mathrm{a}_{\mathrm{n}} \mathrm{a}_{\mathrm{j}} \in[0,1], \quad \sum_{\mathrm{i}=1}^{\mathrm{n}} \mathrm{a}_{\mathrm{i}}=1\right.$.

Fuzzy Evaluation Matrix. A fuzzy mapping is established from the factor set to the evaluation set. f: $U \rightarrow F(V), \mathrm{u}_{\mathrm{i}} \rightarrow \mathrm{r}_{\mathrm{i} 1} / \mathrm{v}_{1}+\mathrm{r}_{\mathrm{i} 2} / \mathrm{v}_{2}+\mathrm{r}_{\mathrm{i} 3} / \mathrm{v}_{3}+\cdots \mathrm{r}_{\mathrm{im}} / \mathrm{v}_{\mathrm{m}}, 0 \leq \mathrm{r}_{\mathrm{ij}} \leq 1, \mathrm{i}=1,2, \cdots, \mathrm{n}, \mathrm{j}=1,2, \cdots, \mathrm{m}$.Then, fuzzy evaluation matrix $R=\left(\mathrm{r}_{\mathrm{ij}}\right)_{\mathrm{n} \times \mathrm{m}}$ is generated based on $\mathrm{r}_{\mathrm{ij}}$.

\section{Application Examples}

Determine the index weight. Based on the above evaluation steps, a fuzzy comprehensive evaluation on man-machine display and control system of a new type armored vehicle is conducted. Six experts who are familiar with the display and control system of the armored vehicles are invited in the evaluation process. The results of index weights are given by the experts in accordance with the method for determining the weight set. 10 experienced armored vehicle crews responsible for different duties are invited to vote for the evaluation of the factors set combined with typical combat missions[5]. The weights and scores of factors set of human-computer display and control system are shown in Table 2.

Establish the levels of fuzzy evaluation matrixes. According to Table 2, we can get the evaluation matrix $R_{1}=\left[\begin{array}{ccccc}0.2 & 0.4 & 0.2 & 0.2 & 0 \\ 0.3 & 0.3 & 0.3 & 0.1 & 0 \\ 0.4 & 0.2 & 0.3 & 0.1 & 0 \\ 0.2 & 0.3 & 0.3 & 0.2 & 0\end{array}\right]$,the weight set $\omega_{1}=(0.20,0.27,0.27,0.26)$.

Based on Fuzzy Comprehensive evaluation formula, $B=\omega \circ R=\left(\mathrm{b}_{1}, \mathrm{~b}_{2}, \cdots \mathrm{b}_{\mathrm{m}}\right)$ ( $\circ$ is the fuzzy operator)

We can get the result of Comprehensive evaluation is $B_{1}=(0.2810,0.2930,0.2800,0.1460,0)$ Similarly available:

$B_{2}=(0.3900,0.3400,0.2350,0.0350,0) ; B_{3}=(0.4000,0.3400,0.2040,0.0560,0)$;

$B_{4}=(0.3750,0.3450,0.1750,0.1050,0) ; B_{5}=(0.1940,0.3540,0.3940,0.0580,0)$.

After being arranged: $R=\left[\begin{array}{lllll}0.2810 & 0.2930 & 0.2800 & 0.1460 & 0 \\ 0.3900 & 0.3400 & 0.2350 & 0.0350 & 0 \\ 0.4000 & 0.3400 & 0.2040 & 0.0560 & 0 \\ 0.3750 & 0.3450 & 0.1750 & 0.1050 & 0 \\ 0.1940 & 0.3540 & 0.3940 & 0.0580 & 0\end{array}\right]$.

Table 2 Evaluation results of the display and control system

\begin{tabular}{|c|c|c|c|c|c|c|c|c|}
\hline \multicolumn{4}{|c|}{ Factor set } & \multicolumn{5}{|c|}{ Evaluation Set } \\
\hline $\begin{array}{c}\text { primary factor } \\
\text { set }\end{array}$ & weight & secondary factor set & weight & good & better & general & worse & bad \\
\hline \multirow{4}{*}{$\begin{array}{c}\text { synthetic display } \\
\text { level }\end{array}$} & \multirow{4}{*}{0.20} & Display visibility & 0.20 & 2 & 4 & 2 & 2 & 0 \\
\hline & & $\begin{array}{c}\text { Display timely } \\
\text { degree }\end{array}$ & 0.27 & 3 & 3 & 3 & 1 & 0 \\
\hline & & Display accuracy & 0.27 & 4 & 2 & 3 & 1 & 0 \\
\hline & & Display Reliability & 0.26 & 2 & 3 & 3 & 2 & 0 \\
\hline \multirow{3}{*}{$\begin{array}{c}\text { Integrated } \\
\text { technical Level }\end{array}$} & \multirow{3}{*}{0.20} & Technical nature & 0.45 & 5 & 3 & 2 & 0 & 0 \\
\hline & & Integrated degree & 0.35 & 3 & 3 & 3 & 1 & 0 \\
\hline & & Intellection degree & 0.20 & 3 & 5 & 2 & 0 & 0 \\
\hline \multirow{5}{*}{$\begin{array}{l}\text { Composite } \\
\text { control level }\end{array}$} & \multirow{5}{*}{0.28} & Control accuracy & 0.20 & 6 & 1 & 2 & 1 & 0 \\
\hline & & $\begin{array}{c}\text { Control timely } \\
\text { degree }\end{array}$ & 0.22 & 5 & 2 & 3 & 0 & 0 \\
\hline & & $\begin{array}{c}\text { Control } \\
\text { Reliability }\end{array}$ & 0.22 & 2 & 6 & 2 & 0 & 0 \\
\hline & & Control simplicity & 0.18 & 4 & 5 & 1 & 0 & 0 \\
\hline & & Control rationality & 0.18 & 3 & 3 & 2 & 2 & 0 \\
\hline \multirow{2}{*}{$\begin{array}{l}\text { Man-machine } \\
\text { effectiveness }\end{array}$} & \multirow{2}{*}{0.20} & Visual effect & 0.18 & 6 & 3 & 0 & 1 & 0 \\
\hline & & Auditory effect & 0.16 & 5 & 2 & 2 & 1 & 0 \\
\hline
\end{tabular}




\begin{tabular}{|c|c|c|c|c|c|c|c|c|}
\hline \multirow[t]{6}{*}{ level } & & Handling Effect & 0.22 & 2 & 6 & 2 & 0 & 0 \\
\hline & & Lighting Effect & 0.07 & 3 & 1 & 5 & 1 & 0 \\
\hline & & Vibration Effect & 0.08 & 3 & 2 & 2 & 3 & 0 \\
\hline & & Noise effect & 0.10 & 4 & 4 & 2 & 0 & 0 \\
\hline & & Harmful gas & 0.09 & 2 & 6 & 2 & 0 & 0 \\
\hline & & $\begin{array}{l}\text { Allocation } \\
\text { rationality }\end{array}$ & 0.10 & 4 & 4 & 1 & 1 & 0 \\
\hline \multirow{3}{*}{$\begin{array}{c}\text { Man-machine } \\
\text { coordination } \\
\text { Level }\end{array}$} & \multirow{3}{*}{0.12} & $\begin{array}{c}\text { Man-machine } \\
\text { Matching }\end{array}$ & 0.32 & 1 & 6 & 2 & 1 & 0 \\
\hline & & $\begin{array}{c}\text { Function } \\
\text { assignment } \\
\text { rationality }\end{array}$ & 0.42 & 2 & 5 & 2 & 1 & 0 \\
\hline & & $\begin{array}{l}\text { Human-machine } \\
\text { dialogue degree }\end{array}$ & 0.26 & 3 & 3 & 2 & 1 & 1 \\
\hline
\end{tabular}

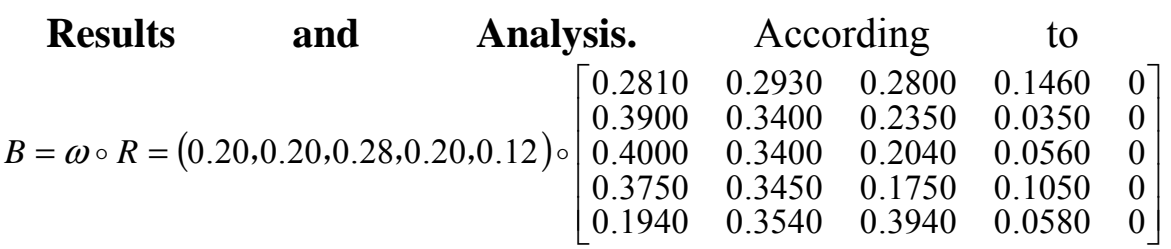

the

formula

$(0.3445,0.3333,0.2424,0.0798,0)$.

Comprehensive evaluation of the display and control system score: $Q=(0.3445,0.3333,0.2424,0.0798,0) \circ(95,85,75,65,55)^{T}=84.425$.

We can see from the comprehensive evaluation score, the crew is quite satisfied with the display and control system of the armored vehicle.

\section{Conclusions}

This paper presents a multi-level fuzzy comprehensive evaluation method which is benefit for improving the evaluation effect. Starting with the establishing of a multi-level evaluation index system form the man-machine engineering point of view, this paper determined the evaluation factors, weight values of the factors, fuzzy evaluation matrix, and the comprehensive evaluation method. Finally a quantitative evaluation result was unfolded. It has important significance for the evaluation of the man-machine display and control systems.

\section{References}

[1]Cao Weiguo and Liu Weiping. Applications of Fuzz Comprehensive Evaluation Based on AHP Defined Weighing in Man-machine System of Armored Vehicle Cabin,J. Journal of Academy of Armored Force Engineering,2008,(22)5:36-39.

[2]Liang Guanhui and Zhu Yuanchang. Application Research on Improved Fuzzy Synthetic Evaluation Model in Efficiency Evaluation of Certain Weapon System,J.Journal of System Simulation,2009,(21)2:60-63.

[3]Braithwaite MG, Durnford SJ, Wildzunas RM. Simulation test of a novel display to minimize the risk of spatial disorientation .AIAA, 975528,1997.

[4]Liang Baohua and Hou Yuhong. Research on Flight Test and Evaluation Method for Display-Control Management System,J. Avionics Technology,2011,(42)3:12-16.

[5] He Jiangtao and Zhou Yi. Comprehensive Fuzzy and Entropy Weight Evaluation of Anti-Aircraft Gun System's Protection Ability[J]. Armament Automation,2008,27(2):25-26. 